\title{
Penerapan Model Pembelajaran Kooperatif Tipe TGT terhadap Hasil Belajar Siswa pada Materi Menulis Cerpen
}

\author{
Hendra \\ MAS PP Darul Quran Medan \\ Email: hendrasope@gmail.com
}

\begin{abstract}
Abstrak
Penelitian ini bertujuan untuk mengetahui peningkatan hasil belajar siswa dan aktivitas siswa dengan menggunakan model pembelajaran kooperatif tipe TGT di kelas. Metode yang digunakan dalam penelitian ini adalah penelitian tindakan kelas yang terdiri dari 2 (dua) siklus. Teknik analisis dalam penelitian ini adalah instrumen 1 tentang tes hasil belajar siswa dan instrumen 2 tentang aktivitas siswa. Hasil tes awal menunjukkan nilai rata-rata kemampuan awal siswa adalah 33,3 dan setelah diterapkan model pembelajaran kooperatif tipe TGT terjadi peningkatan pada Siklus I hasil belajar siswa adalah 66,7 dan pada Siklius II menjadi 86,7.Berdasarkan hasil observasi aktivitas belajar siswa pada Siklus I adalah $60,85 \%$ dan pada Siklus II menjadi 93,35\%. Berdasarkan data di atas dapat disimpulkan bahwa Penerapan Model Pembelajaran Kooperartif Tipe TGT dapat meningkatkan kemampuan menulis cerpen siswa MAS PP Darul Qur'an T.P. 2019/2020.
\end{abstract}

Kata-kata kunci: Model Pembelajaran Kooperatif Tipe TGT, Hasil Belajar, Menulis Cerpen

\section{Application of TGT Type Cooperative LearningModels On Student Learning Outcomes In Cerpen Writing}

\author{
Hendra \\ MAS PP Darul Quran Medan \\ Email: hendrasope@gmail.com
}

\begin{abstract}
This study aims to determine the improvement of student learning outcomes and student activites using the cooperative learning type TGT in class. The method used in this study is classroom action research consisting of two cycles. The analysis technique in this study is instrument I about student learning outcomes testing and instrument II about student activity. The results of pre test showed the average value of pre tsest ability of students was 33,3 and after applying the TGT type cooperative learning model there was an increase in cycles I, student learning outcomes become 66,7 and in cycle II become 86,7. Based on observations of student learning activities in cycle I is 60,85\% and cycle II becomes 93,35\%. Besed on the above data it can be concluded that the application of the TGT type cooperative learning model can improve students' Cerpen writing skills of MAS PP Darul Qur'an T.P 2019/2020.
\end{abstract}

Keywords: TGT Type Cooperative Learning Models, Learning Outcomes, Cerpen Writing 


\section{PENDAHULUAN}

Pelajaran Bahasa Indonesia dianggap kurang menarik bagi siswa bahkan sering menjadi momok menakutkan bagi kalangan pelajar mulai dari siswa Sekolah Dasar (SD) hingga Sekolah Menengah Akhir (SMA). Hal ini dilihat dari nilai Ujian Nasional mata pelajaran Bahasa Indonesia yang merosot dari mata pelajaran lainnya. Berdasarkan hasil observasi tentang hasil belajar siswa pada mata pelajaran Bahasa Indonesia, terutama pada materi pokok menulis cerita pendek hanya sekitar 33,3 \% siswa yang memenuhi standar kelulusan minimal (Priyatni, 2016).

Menulis cerita pendek sering digunakan oleh guru dengan menggunakan metode konvensional dimana siswa dipandang sebagai subjek yang belum mengetahui apapun dan hanya menerima dari gurunya sehingga siswa menjadi pasif didalam pembelajaran. Kemampuan menulis sangat penting namun sering dihindari oleh siswa karena siswa menganggap hal itu sangat sulit dilakukan (Alghifary, 2009).

Tujuan Penelitian ini untuk mengetahui peningkatan hasil belajar siswa dengan menggunakan model pembelajaran kooperatif tipe TGT di kelas. Selain itu juga penelitian ini bertujuan untuk mengetahui aktivitas siswa selama mengikuti pembelajaran dengan menggunakan model pembelajaran kooperatif tipe TGT.
Belajar adalah proses perubahan perilaku berkat pengalaman dan latihan. Artinya tujuan kegiatan belajar adalah perubahan tingkah laku, baik yang menyangkut pengetahuan, keterampilan maupun sikap bahkan meliputi segenap aspek organisme atau pribadi (Djamarah, 2005). Salah satu alternatif yang dapat diambil dalam pembelajaran sastra khususnya dalam pembelajaran menulis cerpen yakni dengan menggunakan model pembelajaran yang tepat dan dianggap dapat memberi pengaruh positif terhadapa pembelajaran menulis cerpen (Sadikin, 2010). Penggunaan model atau metode yang inovatif dapat menciptakan pembelajaran sastra yang lebih kreatif dan menarik perhatian siswa. Alternatif pembelajaran yang digunakan pada penelitian ini yakni dengan model pembelajaran Kooperatif tipe Team Games Tournament (TGT).

Model pembelajaran TGT adalah salah satu tipe model pembelajaran kooperatif yang mudah diterapkan, melibatkan aktivitas seluruh siswa tanpa harus ada perbedaan status, melibatkan peran siswa sebagai tutor sebaya dan mengandung unsur permainan dan reinforcement (Jhonson, 2007). Aktivitas belajar dengan permainan yang dirancang dalam pembelajaran kooperatif tipe TGT memungkinkan siswa dapat belajar lebih rileks disamping menumbuhkan tanggung jawab, kejujuran, kerja sama, persaingan sehat dan keterlibatan belajar. 
Tabel. 1 Langkah-langkah pembelajaran kooperatif

\begin{tabular}{ll}
\hline \multicolumn{1}{c}{ Fase } & \multicolumn{1}{c}{ Tingkah laku } \\
\hline Fase I & Guru memberi informasi kepada siswa dengan demonstrasi atau \\
Penyajian kelas & naskah . \\
Fase II & Guru membentuk kelompok. Siswa bersama kelompoknya \\
Kelompok (Team) & mendalami materi dan mempersiapkan anggota kelompok agar \\
& bekerja dengan optimal pada saat game. \\
Fase III & Siswa memilih kartu bernomor dan mencoba menjawab pertanyaan \\
Game & yang sesuai dengan nomor itu. Siswa yang menjawab benar \\
& pertanyaan akan mendapat skor. \\
Fase IV & Untuk memulai pertandingan masing - masing peserta mengambil \\
Turnamen & nomor undian. Siswa yang mendapat nomor terbesar reader 1 dan \\
& nomor terbesar selanjutnya sebagai challenger 1 dan seterusnya. \\
Fase V & Guru mengumumkan kelompok yang menang. Masing - masing \\
Penghargaan kelompok & team akan mendapat sertifikat atau hadiah apabila rata -rata skor \\
(team recognise) & memenuhi kriteria yang ditentukan. \\
\hline
\end{tabular}

\section{METODE}

Dalam penerapan model pembelajaran kooperatif tipe TGT ini maka diterapkan melalui penelitian tindakan kelas (classroom action research) yang terdiri dari 2 (dua) siklus dengan langkah-langkah: a) perencanaan, b) tindakan, c) pengamatan, d) refleksi (Suharsimi, 2009). Variabel bebas dalam penelitian ini adalah model pembelajaran Kooperatif tipe TGT. Variabel terikat dalam penelitian ini adalah hasil belajar siswa. Populasi dalam penelitian ini adalah seluruh siswa kelas X MAS PP Darul Quran Medan tahun pelajaran 2019/2020. Sampel dalam penelitian ini adalah kelas $\mathrm{X}$ IPA MAS PP Darul Quran Medan tahun pelajaran 2019/2020.
Instrument penelitian ini berupa soal tes bentuk multiple choice terdiri dari dua bagian, yaitu: soal dan option. Selian iu juga menggunakan lembar observasi untuk mengetahui aktivitas siswa di dalam kelas selama proses pembelajaran berlangsung digunakan lembar aktivitas yang telah disesuaikan dengan model pembelajaran kooperatif tipe TGT (Suharsimi, 2012). Teknik analisis data tes hasil belajar dilakukan dengan cara penilaian terhadap skor yang diperoleh digunakan persamaan :

Skor $=\frac{\mathrm{B}}{\mathrm{N}} \times 100$

(Hariati, 2007)

Keterangan:

$\mathrm{B}=$ butir soal yang dijawab benar

$\mathrm{N}=$ banyaknya butir soal 
Analisis data observasi aktivitas siswa dilakukan uji distribusi proporsi dengan persamaan sebagai berikut:

$\mathrm{A}=\frac{\mathrm{Y}}{\mathrm{N}} \times 100 \%$

Keterangan:

$\mathrm{A}=$ persentase aktivitas yang diamati

$\mathrm{Y}=$ jumlah siswa yang melakukan aktivitas

$\mathrm{N}=$ jumlah seluruh siswa

\section{HASIL DAN PEMBAHASAN}

Sebelum siklus pembelajaran diterapkan diadakan tes awal untuk mengetahui kemampuan awal siswa. Setelah diadakan tes awal maka diterapkan siklus pembelajaran yang pertama dan setiap hasil pembelajaran diadakan tes akhir. Data-data tersebut dapat dilihat pada tabel 1 berikut:

Tabel 1. Perbandingan skor hasil pembelajaran Bahasa Indonesia

\begin{tabular}{ccc}
\hline No & Hasil Belajar & Rata-rata \\
\hline 1 & Tes Awal & 33,3 \\
2 & Siklus I & 66,7 \\
3 & Siklus II & 86,7 \\
\hline
\end{tabular}

Selama pembelajaran yang diterapkan peneliti dilakukan pengambilan data aktivitas siswa. Kemudian data-data pengamatan tersebut dikumpulkan dan dianalisis, maka diperoleh data seperti tabel 2 dibawah ini.

Tabel 2. Perbandingan data observasi aktivitas siswa

\begin{tabular}{|c|c|c|c|}
\hline No & Aktivitas yang diamati & $\begin{array}{c}\text { Siklus I } \\
(\%)\end{array}$ & $\begin{array}{c}\text { Siklus II } \\
(\%)\end{array}$ \\
\hline 1 & Menulis & 83,3 & 100 \\
\hline 2 & Mengerjakan tugas & 80 & 90 \\
\hline 3 & Bertanya pada sesama dalam kelompok & 50 & 96,7 \\
\hline 4 & Bertanya pada guru & 46,7 & 90 \\
\hline \multirow[t]{2}{*}{5} & Tindakan yang tidak relevan dengan KBM & 16,6 & 3,3 \\
\hline & Rata-rata aktivitas & 60,85 & 93,35 \\
\hline
\end{tabular}

Merujuk pada tabel 1 dapat diketahui bahwa nilai rata-rata tes awal yang diperoleh siswa adalah sebesar 33,3 dimana tidak ada siswa yang nilainya mencapai KKM yang ditetapkan. Melihat nilai tersebut peneliti membuat perencanaan untuk menerapkan pembelajaran kooperatif tipe TGT dalam upaya meningkatkan hasil belajar siswa.

Setelah pembelajaran dengan model kooperatif tipe TGT selesai dilaksanakan, siswa diberikan evaluasi untuk mengetahui tingkat pemahaman siswa dalam menulis 
cerpen. Dari hasil analisis data tentang tes hasil belajar siklus I diperoleh nilai rata-rata hasil belajar siswa sebelar 66,7 (tuntas namun belum maksimal).

Hasil analisis dan evaluasi pada siklus I dijadikan bahan refleksi bagi peneliti untuk kemudian merencanakan tindakan perbaikan untuk pembelajaran pada siklus II. Pembelajaran pada siklus II didasarkan pada tindakan-tindakan yang telah direncanakan sebelumnya oleh peneliti. Merujuk pada tabel II dapat diketahui bahwa hasil belajar siswa pada siklus II adalah sebesar 86,7 (tuntas).

Selama proses pembelajaran peneliti juga melakukan pengamatan untuk memperoleh data aktivitas siswa selama Kegiatan Belajar Mengajar (KBM). Merujuk pada tabel II bahwa siswa yang aktif menulis pada siklus I hanya $83,3 \%$, yang aktif mengerjakan tugas $80 \%$, siswa yang aktif bertanya pada sesame dalam kelompok hanya $50 \%$ dan siswa yang aktif bertanya pada guru hanya 46,7\%. Pada siklus ini masih terdapat siswa yang melakukan tindakan yang tidak relevan dengan KBM sebesar 16,6\%. Hal ini mungkin terjadi karena siswa tidak terbiasa dalam berkelompok disebabkan selama ini siswa tidak dibiasakan berkelompok dalam pembelajaran.

Selama proses pembelajaran juga dilakukan observasi untuk memperoleh data aktivitas pada siklus II. Merujuk pada tabel 2 diperoleh data bahwa aktivitas siswa mengalami peningkatan yang sangat baik. Dari tabel tersebut diketahui bahwa pensentase rata-rata aktivitas menulis sudah 100\%, aktivitas mengerjakan tugas 90\%, aktivitas bertanya kepada sesama dalam kelompok 96,7\%, aktivitas bertanya pada guru $90 \%$, dan aktivitas yang tidak relevan dengan KBM hanya 3,3\%. Artinya hanya ada satu orang siswa saja yang kurang konsentrasi selama KBM berlangsung, sehingga dapat disimpulkan bahwa aktivitas siswa pada siklus II sudah sangat baik.

\section{SIMPULAN DAN SARAN}

Hasil tes awal menunjukkan nilai ratarata kemampuan awal siswa adalah 33,3 dan setelah diterapkan model pembelajaran kooperatif tipe TGT terjadi peningkatan terhadap hasil belajar siswa. Pada siklus I nilai rata-rata hasil belajar siswa 66,7 dan pada siklus II meningkat menjadi 846,7sehingga seluruh siswa dinyatakan tuntas telah mencapai standar kelulusan minimal.

Berdasarkan hasil observasi aktivitas siswa pada siklus I aktivitas menulis 83,3\% (25 siswa), mengerjakan tugas 80\% (24 siswa), bertanya pada sesame dalam kelompok $50 \%$ (15 siswa), bertanya pada guru 46,7\% (14 siswa), tindakan yang tidak relevan dengan KBM 16,6\% (5 siswa). Pada siklus II terjadi peningkatan aktivitas siswa. Pada aktivitas menulis $100 \%$ (30 siswa), mengerjakan tugas 90\% (27 siswa), bertanya pada sesame dalam kelompok 96,7\% (29 siswa), bertanya 
pada guru 90\% (27 siswa), dan tindakan yang tidak relevan dengan KBM 3,3\% (1 siswa). Simpulan penelitian ini yaitu model pembelajaran kooperatif mampu meningkatan terhadap hasil belajar siswa.

\section{DAFTAR REFERENSI}

Alghifary, W. (2009). Sihir Terakhir: Analogi Puisi Penyair Perempuan ASAS. Pustaka Pujangga.

Djamarah, S. (2005). Belajar Pembelajaran. UNIMED Press.

Hariati, M. (2007). Model dan Teknik Penilaian pada Tingkat Satuan. Gaung Persada Press.

Jhonson, B. E. (2007). Contextual Teaching and Learning. MLC.

Priyatni, H. (2016). Bahasa dan Sastra Indonesia SMA/SMK/MA. Bumi Aksara.

Sadikin, M. (2010). Kumpulan Sastra Indonesia Edisi Terlengkap. Gudang Ilmu.

Suharsimi, A. (2009). Penelitian Tindakan Kelas. Bumi Aksara.

Suharsimi, A. (2012). Dasar-dasar Evaluasi Pendidikan. In Bumi Aksara. 